\title{
Enteropathogenic Escherichia coli in a treated effluent from Puebla City-Mexico, resistant to antibiotics and heavy metals
}

\author{
Edith Chávez-Bravo ${ }^{1,}{ }^{*}$, Claudia Cecilia Cordero-Arellano ${ }^{2}$, Alejandro IA Alonso-Calderón ${ }^{3}$ and Antonio \\ Rivera ${ }^{1}$ \\ ${ }^{1}$ Centro de Investigaciones en Ciencias Microbiológicas, Instituto de Ciencias de la Benemérita Universidad Autónoma de \\ Puebla, México. \\ ${ }^{2}$ Facultad de Ciencias Biológicas de la Benemérita Universidad Autónoma de Puebla, México. \\ ${ }^{3}$ Facultad de Ingenieria Química de la Benemérita Universidad Autónoma de Puebla, México.
}

Publication history: Received on 02 June 2020; revised on 11 June 2020; accepted on 14 June 2020

Article DOI: https://doi.org/10.30574/gscarr.2020.3.3.0045

\begin{abstract}
The Atoyac river in the City of Puebla has become a receptor for industrial and domestic discharges, with microbial load being one of the most persistent pollutants even after treatment. Microbial load is an important factor for public health since pathogenic bacteria cause infectious diseases with different levels of severity. Chemical contaminants such as heavy metals and antibiotics are the cause of anthropogenic activities and their indiscriminate use. Because this river is a receptor for these pollutants, the objective of this study was to identify the presence of enteropathogenic E. coli (EPEC) and determine its resistance to antibiotics and heavy metals. 113 strains of E. coli isolated from the Atoyac river wastewater were characterized using the polymerase chain reaction (PCR) technique, as well as their resistance to 12 antibiotics, as well as their resistance to $\mathrm{Co}$, Mo, $\mathrm{Fe}$. , $\mathrm{Cu}$ and $\mathrm{Pb}$. The results showed that $85 \%$ of the strains belong to the EPEC pathotype, $77 \%$ (87/113) presented resistance to at least 1 type of antibiotic, only $24 \%$ had multi-resistance and all the strains had resistance to $\mathrm{Mo}$ and $\mathrm{Fe}$, for $\mathrm{Co}$ and $\mathrm{Cu}$ they only presented medium resistance, before $\mathrm{Pb}$ only $5.3 \%(6 / 113)$ of the total of the strains presented resistance and 69\% (78/113) presented only medium resistance. The results obtained reveal the presence of EPEC, a causal etiologic agent for diarrheal outbreaks capable of surviving and having resistance to antibiotics and metals, a result that supports the concern to pay attention to the health of the Atoyac river wastewater to avoid future infections in communities surrounding.
\end{abstract}

Keywords: EPEC; Effluent; Antibiotics; Heavy metals; México

\section{Introduction}

The current world scenario of intense demographic growth and urban activities have caused the contamination of water bodies, with developing countries being the most affected. Among the main pollutants we find industrial and domestic wastewater discharges that are discharged into rivers without receiving adequate treatment. The release of toxic compounds such as heavy metals, as well as the release of pathogenic bacteria resistant to antibiotics present in wastewater constitute a major problem for the environment and for public health [1-3]. The misuse of antibiotics in medical, veterinary and agricultural practices has led to the development of resistance and microbial multi-resistance to these compounds, reducing the effectiveness of established treatments and increasing mortality rates. Likewise, exposure to the toxic effects of heavy metals has allowed the appearance and selection of bacteria with mechanisms capable of tolerating their harmful effects [4-6].

In Mexico, water pollution is derived from deficiencies in wastewater treatment systems and sanitation means, causing public health problems such as the increase in gastrointestinal diseases, especially among children under five years of

\footnotetext{
${ }^{*}$ Corresponding author: Edith Chávez-Bravo
} 
age, being one of the factors that cause deaths in the country. Among the bacterial pathogens that cause these diseases, we find diarrhogenic E. coli pathotypes as one of the most important etiological agents associated with wastewater contamination and as one of the main contributors to these diseases $[7,8]$.

The Atoyac river in the state of Puebla is considered one of the most polluted rivers in Mexico, which is extremely impacted by wastewater from discharges from urban, agricultural and industrial sources. Therefore, the consequences that the contamination of this river can generate that turns it into a reservoir of microorganisms capable of generating resistance to antibiotics and heavy metals, is a matter of concern [7].

In relation to the above, the objective was to determine the existence of enteropathogenic E. coli (EPEC) in a treated effluent from the city of Puebla resistant to antibiotics and heavy metals.

\section{Material and methods}

\subsection{Strain recovery procedure}

One hundred thirteen E. coli strains were used corresponding to a previous annual monitoring carried out in 2016 in the effluent of the Atoyac river in Puebla city, these strains were protected in the microbial pathogenicity laboratory of the Center for Research in Microbiological Sciences of Benemerita Universidad Autonoma de Puebla. The samples were kept in cryovials with Luria Bertani broth at a temperature of $-70^{\circ} \mathrm{C}$.

For use, the $E$. coli strains were thawed, seeded dropwise in plates with MacConkey agar and incubated at $37 \pm 1{ }^{\circ} \mathrm{C}$ for 24 hours, after 24 hours incubation, the plates were checked and the strains were examined for contamination.

\subsection{Molecular detection of EPEC strains}

Detection of the virulence genes eae (384 bp) and bfpA (324 bp) of the EPEC strains was carried out through the polymerase chain reaction (PCR), for this procedure the isolated E. coli strains were seeded in MacConkey agar for 24 hours at $37 \pm 1^{\circ} \mathrm{C}$, subsequently the strains were checked for contamination, they were cross-streaked in Luria Bertani agar and incubated for 24 hours at $37 \pm 1{ }^{\circ} \mathrm{C}$.

Subsequently, the DNA of the strains was extracted using the heat shock technique, and the PCR was carried out with primers specific for the virulence genes of EPEC that encode Intimina (gene eae) with a molecular weight of $384 \mathrm{bp}$ and Bfp (bfpA gene) with a molecular weight of $324 \mathrm{bp}$, using the E2348/69 strain (EPEC) as a control. Subsequently, the samples were placed in a TECHNE model: TC-412 thermal cycler and programmed to carry out the specific temperature cycles for the PCR (Prewarming $105{ }^{\circ} \mathrm{C}$, denaturation $94{ }^{\circ} \mathrm{C} / 5$ minutes, followed by 30 cycles $\left(94{ }^{\circ} \mathrm{C} / 30\right.$ seconds, 55 ${ }^{\circ} \mathrm{C} / 30$ seconds, $72{ }^{\circ} \mathrm{C} / 30$ seconds), extension temperature $72{ }^{\circ} \mathrm{C} / 5$ minutes and final temperature $10{ }^{\circ} \mathrm{C}$.

Once the PCR samples were obtained, electrophoresis was performed on 1.5\% agarose gels to observe the amplification of the genes of the strains. Subsequently, the gel was stained with ethidium bromide and rinsed in distilled water, then placed in a UV transilluminator to visualize the amplified bands of the EPEC virulence genes.

\subsection{Determination of antibiotic resistance}

All the strains were subjected to the Kirby-Bauer technique to determine their sensitivity to 12 antimicrobials: Ampicillin (AM), Carbenicillin (CB), Cephalothin (CF), Cefotaxime (CFX), Ciprofloxacin (CPF), Chloramphenicol (CL), Nitrofurantoin (NF), Amikacin (AK), Gentaminycin (GE), Netilmicin (NET), Norfloxacin (NOF), Sulfamethoxazole Trimethoprim (SXT).

For this, the strains were seeded in MacConkey agar for 24 hours at $37 \pm 1^{\circ} \mathrm{C}$, then they were seeded by cross streak in Luria Bertani agar and incubated for 24 hours at $37 \pm 1{ }^{\circ} \mathrm{C}$, the inoculum were prepared and standardized in $0.85 \%$ saline solution with a turbidity equal to McFarland tube 5 , the strains were subsequently uniformly inoculated by means of sterile swabs in Müller-Hinton agar, the filter paper discs impregnated with the antibiotics were placed and incubated at $37 \pm 1{ }^{\circ} \mathrm{C}$ for 24 hours. After 24 hours of incubation, the inhibition halos were read for their subsequent classification.

The reading of the inhibition halos was made according to the comparison table of halos of sensitivity in mm (NCCLS) belonging to the brand: Diagnostic Research (ID) reference PT-35 Multibac I.D. REG. No. 1159R2002 SSA. According to the measurements in millimeters of the sensitivity halos presented in the antibiotic disks, the strains were classified as resistant (R), intermediate (I) and sensitive (S). 


\subsection{Determination of resistance to heavy metals}

For the determination of resistance to heavy metals, the strains were seeded by means of cross striations on MüllerHinton agar added with the following metals: Cobalt (CoSO4), Molybdate (NaMoO4), Copper (CuCl), Lead (Pb) and Iron $(\mathrm{FeCl} 3)$ at a concentration of $100 \mathrm{ppm}$, they were incubated for 24 hours at $37 \pm 1{ }^{\circ} \mathrm{C}$ and subsequently the resistance to each metal was determined through the observation of microbial growth and its sensitivity in growth inhibition.

In determining the resistance to the different metals, 3 parameters were taken into account: resistant (R) for strains that presented total growth, moderately resistant (MR) to strains with a minimum of growth and sensitive (S) to strains without growth in the middle. In addition, a comparative analysis was performed to determine the number of EPEC strains resistant to antibiotics and heavy metals.

\section{Results}

\subsection{Molecular detection of EPEC strains}

Molecular detection determined that 85\% (96/113) of strains were positive for the EPEC pathogroup by expressing the virulence genes: eae (384 bp) and / or $b f p A(324 \mathrm{bp})$, specific genes that correspond to the EPEC pathogroup. In this study, the control strain E2348/69 was used for comparison with the test strains (Figure 1).

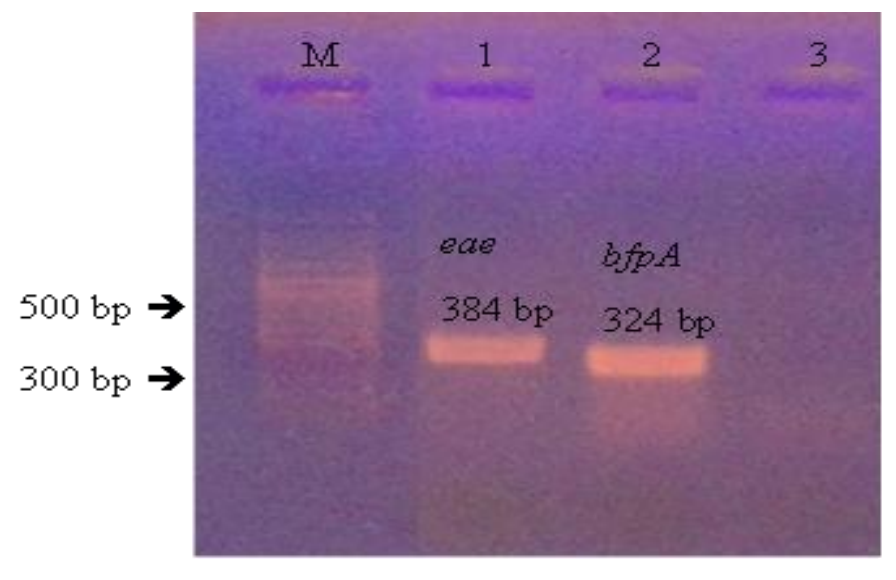

Figure 1 Agarose gel with eae and bfpA amplicons

Lane M: molecular weight marker (1 Kb), 1: eae gene, 2: bfpA gene.

It was obtained that of 85\% (96/113) of strains positive for EPEC, 28.3\% (32/113) expressed both virulence genes eae (384 bp) and $b f p A(324 \mathrm{bp})$ (Figure 2).

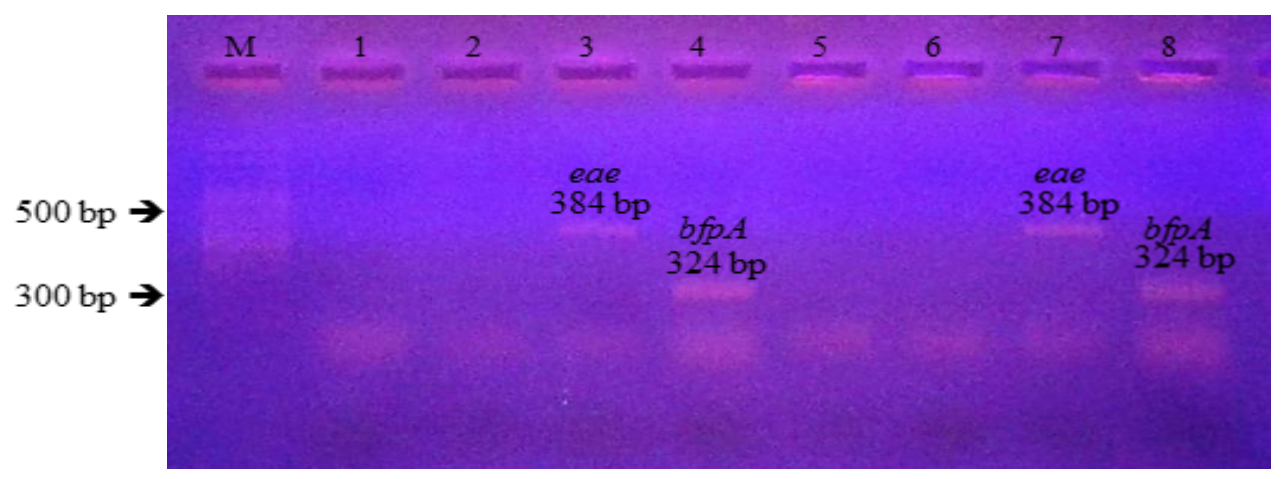

Figure 2 Agarose gel with eae and bfpA amplicons of two E. coli strains (Keys: 1bc and 2a). Lane M: molecular weight marker (1 Kb), 3-4: eae and $b f p A$ gene, 7-8: eae and $b f p A$ gene. 
While 56.6\% (64/113) of the EPEC positive strains only expressed the $b f p A$ virulence gene (Figure 3).



Figure 3 Agarose gel with the $b f p A$ amplicons of three E. coli strains (Keys: 1ac, $2 \mathrm{aB}$ and $2 \mathrm{cb}$ ). Lane M: molecular weight marker $(1 \mathrm{~Kb}), 4: b f p A$ gene, 8: $b f p A$ gene, 12: $b f p A$ gene.

\subsection{Determination of antibiotic resistance}

Of the 113 E. coli strains in this study, 77\% (87/113) presented resistance to at least 1 type of antibiotic, with $31 \%$ (27/87) resistant to 4 or more types of antibiotics, $13.8 \%$ (12/87) resistant to 3 antibiotics, $36.8 \%(32 / 87)$ resistant to 2 antibiotics and $18.4 \%(16 / 87)$ resistant to 1 single antibiotic. While the rest of the strains showed susceptibility to all antibiotics with $23 \%(26 / 113)$.

The E. coli strains showed greater resistance to the antimicrobials Carbenicillin (CB) with $63.7 \%(72 / 113)$ and Ampicillin (AM) with 62.8\% (71/113), they also presented resistance to the antimicrobial Sulfamethoxazole Trimetroprim (SXT) with 23\% (26/113), Chloramphenicol (CL) with 22.1\% (25/113), Cephalothin (CF) with 15\% (17/113), Norfloxacin (NOF) with 11.5\% (13/113), Gentaminycin (GE ) with 10.6\% (12/113), Ciprofloxacin (CPF) with $10.6 \%$ (12/113), Amikacina (AK) 7.1\% (8/113), Nitrofurantoin (NF) with 6.2\% (7/113), Netilmicina ( NET) with 5.3\% (6/113) and Cefotaxima (CFX) with 2.7\% (3/113).

\subsection{Multi-resistance of $E$. coli strains}

Of the total E. coli strains, $23.9 \%$ (27/113) presented multiresistance (resistance to 4 or more different antibiotics), with $7.1 \%(8 / 113)$ being the most predominant strains with resistance to 4 antibiotics, followed by 5.3\% (6/113) to 6 antibiotics, $4.4 \%(5 / 113)$ to 5 antibiotics, $3.5 \%(4 / 113)$ to 7 antibiotics, $1.8 \%(2 / 113)$ to 8 antibiotics and 10 antibiotics respectively. Within this $23.9 \%(27 / 113)$ of multiresistant strains, 23 patterns of antimicrobial resistance were found, of which the most frequent were: AM-CB-CL-SXT present in 3.5\% (4/113) of the strains and AM -CB-CF-CL-NF present in $1.8 \%(2 / 113)$ of the strains, the rest of the standards were represented by $0.9 \%$ of the strains $(1 / 113)$ (Table 1$)$.

\subsection{Determination of resistance to heavy metals}

The resistance present in the E. coli strains was mainly represented by the heavy metals Molybdate (NaMoO4) and Fierro $(\mathrm{FeCl} 3)$.

The 113 strains presented $100 \%(113 / 113)$ resistance to the metals Molybdate $(\mathrm{NaMoO} 4)$ and Iron (FeCl3), against the Lead metal $(\mathrm{Pb})$ only $5.3 \%(6 / 113)$ of the strains were resistant. The strains also showed moderate resistance with $69.9 \%(79 / 113)$ to Cobalt (CoSO4), 69\% (78/113) to Lead (Pb) and 43.4\% (49/113) to Copper (CuCl).

\subsection{Comparison of virulence factors of antibiotic susceptibility and resistance to heavy metals of the EPEC strains}

EPEC strains 85\% (96/113) showed resistance between 1 to 10 antibiotics and 2 heavy metals. 23.9\% (27/113) of the strains presented resistance to 2 antibiotics and 2 heavy metals, 9.7\% (11/113) to 3 antibiotics and 2 heavy metals, another $9.7 \%(11 / 113)$ to 1 antibiotic and 2 metals heavy, 5.3\% (6/113) to 4 antibiotics and 2 heavy metals, 3.5\% (4/113) to 7 antibiotics and 2 heavy metals, $2.7 \%(3 / 113)$ to 6 antibiotics and 2 heavy metals, $4.4 \%(5 / 113)$ to 5 
antibiotics and 2 heavy metals, 1.8\% (2/113) to 10 antibiotics and 2 heavy metals, 1.8\% (2/113) to 8 antibiotics and 2 heavy metals, while $16.8 \%$ (19/113) was susceptible to all antibiotics and had resistance to 2 heavy metals.

The remaining EPEC strains showed resistance between 1 to 6 antibiotics and 3 heavy metals, being 1.8\% (2/113) resistant to 6 antibiotics and 3 heavy metals, 1.8\% (2/113) to 2 antibiotics and 3 heavy metals, $0.9 \%(1 / 113)$ to 1 antibiotic and 2 heavy metals and $0.9 \%$ (1/113) susceptible to antibiotics and resistant to 3 heavy metals.

Table 1 Antibiotic resistance patterns of E. coli strains isolated from the Atoyac river.

\begin{tabular}{|c|c|c|}
\hline Number of antibiotics & Pattern & Strains \\
\hline \multirow[t]{5}{*}{4} & AM-CB-CF-SXT & 1 \\
\hline & AM-CB-CF-CL & 1 \\
\hline & AM-CB-CL-SXT & 4 \\
\hline & AM-CB-GE-NOF & 1 \\
\hline & AM-CB-AK-SXT & 1 \\
\hline \multirow[t]{4}{*}{5} & AM-CB-CF-CFX-SXT & 1 \\
\hline & AM-CB-CPF-NOF-SXT & 1 \\
\hline & AM-CB-CF-GE-SXT & 1 \\
\hline & AM-CB-CF-CL-NF & 2 \\
\hline \multirow[t]{6}{*}{6} & AM-CB-CPF-CL-NOF-SXT & 1 \\
\hline & AM-CB-CF-CPF-NOF-SXT & 1 \\
\hline & AM-CB-CL-GE-NOF-SXT & 1 \\
\hline & AM-CB-CF-CL-NET-NOF & 1 \\
\hline & AM-CB-CPF-CL-GE-NOF & 1 \\
\hline & AM-CB-NF-NET-NOF-SXT & 1 \\
\hline \multirow[t]{4}{*}{7} & AM-CB-CPF-GE-NET-NOF-SXT & 1 \\
\hline & AM-CB-CF-CL-NF-GE-SXT & 1 \\
\hline & AM-CB-CPF-NF-AK-GE-NOF & 1 \\
\hline & AM-CB-CF-CFX-CPF-CL-AK & 1 \\
\hline \multirow[t]{2}{*}{8} & AM-CB-CF-CPF-CL-GE-NOF-SXT & 1 \\
\hline & AM-CB-CF-CPF-CL-NF-NOF-SXT & 1 \\
\hline \multirow[t]{2}{*}{10} & AM-CB-CF-CPF-CL-NF-AK-GE-NET-SXT & 1 \\
\hline & AM-CB-CF-CFX-CPF-CL-GE-NET-NOF-SXT & 1 \\
\hline
\end{tabular}

\section{Discussion}

The data coincide with that reported by Huang et al., (2016) who also identified the presence of EPEC in wastewater from rivers, obtaining that $17 \%(8 / 47)$ of the total of its isolated strains taken from 12 main rivers in Taiwan were identified as EPEC, likewise they sampled 34 points from the Puzih river where they obtained 196 strains of which 28.1\% (55/196) were identified as EPEC, being this E. coli pathotype the one found most frequently in this study [9]. In the same way, Ramírez et al., (2013) analyzed samples taken from the San Pedro river in Aguascalientes where they found the presence of 150 (100\%) strains of E. coli of which 6\% (9/150) was positive for EPEC [10].

Obi et al., (2004) found that of 87.7\% (200/228) of strains identified as E. coli isolated from 6 rivers in the Venda region of South Africa, $67.5 \%(135 / 200)$ had one or more of the genes responsible for the pathogenicity E. coli, with EPEC being one of the strains mostly found with $34.1 \%$ (46/135), of which the $b f p A$ gene was detected more frequently with $26 \%$ (35/135) [11]. 
The presence of EPEC in rivers is mainly due to the wastewater discharges they receive, such as domestic wastewater that contributes high percentages of organic matter and microorganisms of faecal origin. Fecal contamination in surface waters and the presence of pathogens derived from faeces in water is related to infectious diseases $[12,13]$.

Mendez et al., (2010) tell us that the concentrations of coliforms in surface waters imply the presence of bacterial genera of the Enterobacteriaceae family such as Citrobacter, Enterobacter, Escherichia, Hafnia, Klebisella, Serratia and Yersinia [14]. The genus Escherichia being the most representative of fecal contamination and associated with infectious gastrointestinal diseases [15].

Thus, the detection of EPEC strains in rivers derived from surface water contamination indicates a great risk to public health, due to its ability to cause human diseases, such as childhood diarrhea [16].

These results agree with Ramírez et al., (2013) who carried out antimicrobial susceptibility tests of 150 E. coli strains isolated from the San Pedro river in Aguascalientes, Mexico to 13 antibiotics and reported that 52\% (79/150) were resistant to at least 1 antimicrobial agent, 37.3\% (56/150) at least two and 30.6\% (46/150) were multiresistant. Likewise, they found that 39.3\% (59/150) of the strains were resistant to Ampicillin (AM), being the most prevalent resistance, followed by Trimethoprim/Sulfamethoxazole (SXT) with 28.6\% (43/150), Chloramphenicol (CL) with $22 \%$ $(33 / 150)$ and Cefalotina (CF) with $17.3 \%(26 / 150)$ and only $1.33 \%(2 / 150)$ of the strains showed resistance to the antibiotics Netilmicina (NET), Amikacina (AK) and Cefotaxima (CFX) [10].

Rivera et al., (2006) I also carry out sensitivity tests to 12 antibiotics of 100 enterobacteria isolated from the Alseseca river, with $E$. coli being the most frequent with $44 \%(48 / 110)$, where its results revealed that the strains showed a high percentage of resistance. to Carbenicillin (CB) with 87.9\%, being the resistance that appeared the most in all the strains, also resistance to antibiotics ampicillin (AM), Sulfamethoxazole Trimethoprim (SXT), Cefotaxime (CFX), Cephalotin (CF), was also observed. Chloramphenicol (CL), Amikacin (AK) and Nitrofurantoin (NF), while for antibiotics Gentaminycin (GE) and Netilmicin (NET) there was no resistance [17]. On the other hand, Nonotonga et al., (2016) isolated 278 strains of $E$. coli from the Kat River in South Africa and reported the susceptibility profile to 10 antibiotics, their results showed that 98\% (272/278) had resistance to Ampicillin (AM) and 38\% (105/278) to Sulfamethoxazole Trimethoprim (SXT), while for the other antibiotics analyzed the strains did not show significant resistance [18].

In the same way, Chávez et al., (2012) analyzed the susceptibility to 12 antibiotics of 103 strains of $E$. coli isolated from stool samples of children and adults with diarrheal, where their results showed that 87\% (90/103) of the strains presented resistance to at least one antibiotic, where the percentages of resistance to Carbenicillin (CB) and Ampicillin (AM) were the highest, with the most frequent resistance presented by the strains. Likewise, they tell us that resistance markers with high frequency in the population should be confirmed in more extensive studies, to consider the elimination of their use in the treatment of infectious diseases, since in addition to being ineffective, they would further limit the options for antimicrobial therapy [19].

The high percentages of resistance of the E. coli strains to the antibiotics Carbenicillin (CB) and Ampicillin (AM), followed by Sulfamethoxazole Trimetroprim (SXT) and Chloramphenicol (CL) obtained in this study and in previous studies coincide with the high frequency of bacterial resistance to antibiotics that are most frequently used in Mexico for the treatment of infections (Novoa et al. 2016). On the other hand, the antibiotics Cefalotina (CF), Norfloxacina (NOF), Gentamicina (GE), Ciprofloxacina (CPF), Amikacina (AK), Cefotaxima (CFX), Nitrofurantoína (NF), Netilmicina (NET) and Cefotaxima (CFX) showed low resistance percentages, which may be indicative of the low use of these drugs in the indiscriminate treatment of infections [4].

Consequently, the widespread application of antibiotics in human and veterinary medicine has led to the emergence, selection, and spread of antibiotic-resistant bacteria and genes encoding for antibiotic resistance in different environmental sectors such as surface waters. In this way aquatic environments such as rivers and streams are considered ideal reservoirs for the spread of antibiotic resistance, since antimicrobials and antimicrobial resistant bacteria are often released directly into the environment [20].

Regarding the multi-resistance of $E$. coli strains, the results are similar to those obtained by Ramírez et al., (2013) where they found that of 150 E. coli strains isolated from the San Pedro river in Aguascalientes submitted to sensitivity tests to 13 antibiotics with a multi-resistant profile, 13\% (20/150) presented resistance to 3 antibiotics, $7.3 \%(1 / 150)$ to 4 antibiotics, $5.3 \%(8 / 150)$ to 5 antibiotics, 3.3\% (5/150) to 6 antibiotics and $1.3 \%(2 / 150)$ to 7 antibiotics [10]. Likewise, Romeu et al., (2012) analyzed the antimicrobial susceptibility to 15 antibiotics of 113 E. coli strains isolated from 3 rivers (Almendares, Quibú and Luyanó) in Havana, Cuba, where they found that 11.5\% (13/113) of the strains showed resistance against 3 or more antibiotics (multiresistant) and obtained 9 multiresistance patterns of 3 to 7 antibiotics, 
where the most frequent patterns were AMP/CPF/LV with 4 strains (3.5\%), followed by the AMP/ CPF/LV/NF pattern with 2 strains (1.8\%), the rest consisted of a single strain [21].

On the other hand, Chindembele et al., (2015) analyzed one hundred fourteen E. coli strains isolated from urine cultures belonging to patients diagnosed with urinary tract infection from the General Hospital of Huambo, Angola and determined their resistance to 12 antibiotics, where their results showed that the strains presented resistance against more of three antibiotics from different families, so they were considered multiresistant and found 46 patterns of multiresistance against 5 to 10 of the 12 antibiotics evaluated. The most frequent resistance patterns among these strains were: AMP-KZ-SXT-CL-NF with eight strains, KZ-AK-SXT-CRO-CL-NF-IMP and KZ-CRO-CPF-GE-NF-AMP with six strains each, AMP-KZ-SXT-CRO-NF with five strains, while the rest of the standards consisted of 1 to 4 strains [22].

Therefore, the results of this work can be compared with the previous studies reviewed, where there is a multiresistance present in strains of $E$. coli, as well as resistance patterns ranging from 3 antibiotics to 10 antibiotics, which are mostly represented by the antibiotics Ampicillin (Am) and Sulfamethoxazole Trimethoprim (SXT). Delgado et al., (2016) tell us that patterns of resistance to various antibiotics commonly used in therapeutic treatments are considered a threat to public health [23].

Regarding resistance to heavy metals, the results agree with Abskharon et al., (2008) who isolated 12 strains of E. coli from the El-Malah channel in Assiut (Egypt) and determined their tolerance to heavy metals: $\mathrm{Cd}, \mathrm{Cr}, \mathrm{Pb}, \mathrm{Co}, \mathrm{Cu}, \mathrm{Ni}$ and $\mathrm{Zn}$ in concentrations of 0.09 to $12 \mathrm{mM}$, where their results showed that most of the strains grew well at low concentrations of heavy metals and their number gradually decreased as the concentration increased. Likewise, Martínez et al. (2017), evaluated bacterial strains isolated from the Almendares river (Cuba) and found that they presented resistance to the heavy metals Lead $(\mathrm{Pb})$ and Chromium $(\mathrm{Cr})$ in concentrations of 0.5, 1.0 and $1.5 \mathrm{mM}$ [24].

On the other hand, Chávez et al., (2007) determined the resistance to 8 heavy metals ( $\mathrm{Fe}, \mathrm{Co}, \mathrm{Mo}, \mathrm{Pb}, \mathrm{Ni}, \mathrm{Cu}, \mathrm{Hg}$ and $\mathrm{V}$ ) at two concentrations $(1,000$ and 2,000 ppm) of 48 strains of $E$. coli isolated from adult patients with diarrheal symptoms. from the city of Puebla, where their results showed that all the strains were resistant to heavy metals $\mathrm{Fe}$, $\mathrm{Mo}, \mathrm{V}, \mathrm{Cu}, \mathrm{Ni}$ and $\mathrm{Pb}$ and only $35.4 \%$ were resistant to $\mathrm{Co}[25]$.

Therefore, with the results obtained in this study and what was reviewed in previous studies, the resistance of $E$. coli to heavy metals is shown, which is in agreement with what Cervantes et al., (2006) where he proposes that exposure to metals selects and maintains microbial variants capable of tolerating and resisting its harmful effects [6].

The presence of high concentrations of heavy metals in anthropogenic sites or natural ecosystems represents a permanent selective pressure, recalcitrant and widely distributed, with environmental importance, which has contributed to the emergence and dispersal of new microbial genotypes that determine resistance to metals [26].

Likewise, the presence of the heavy metals $\mathrm{Fe}, \mathrm{Mo}, \mathrm{Pb}, \mathrm{Cu}$ and $\mathrm{Co}$ in the Atoyac river can be related to the discharge of industrial discharges received by the effluent [27].

In comparing the virulence factors of antibiotic susceptibility and their resistance to heavy metals of the EPEC strains, the results obtained can be compared with those of Lamprecht et al., (2014) who analyzed water samples from the Plankenburg River (Stellenbosch, Western Cape Province) and identified 81 strains of $E$. coli of which 4 strains belonged to the EPEC group and presented resistance to 5 antibiotics (AM, CL, TCY, TMP and SM) [28]. In the same way, Adefosoye et al., (2016) analyzed final effluent water samples discharged from two wastewater treatment facilities in the Eastern Cape Province of South Africa, where they identified 223 presumptive E. coli isolates of which 17 (7.6\%) strains belonged to the pathogroup. EPEC that in turn presented resistance to 11 antibiotics, highlighting the antibiotics: AM, CFX, CL, CIP, NOF, S and TET [29].

Likewise, Novoa et al., (2017) analyzed 614 strains of bacteria isolated from patients of all ages with acute diarrhea from 4 cities in southeastern Mexico, where their results showed that $77 \%$ of the strains analyzed corresponded to the E. coli enteropathogenic serotype (EPEC), obtaining that this pathogroup presented resistance to 8 antimicrobials, of which the following stand out: AM, CL, CIP and SXT [30]. On the other hand, Chávez et al., (2007) analyzed a total of 48 strains of $E$. coli isolated from adult patients with diarrheal disease in the city of Puebla, where they found that $30 \%$ $(14 / 48)$ of the strains belonged to the EPEC category, which presented high resistance to 6 heavy metals $(\mathrm{Fe}, \mathrm{Mo}, \mathrm{V}, \mathrm{Cu}$, $\mathrm{Ni}$ and $\mathrm{Pb}$ ) [25].

The results obtained in this study show that the EPEC pathogroup isolated from the Atoyac river showed resistance to antibiotics and heavy metals, which is consistent with previous studies. Veranes (2013) tells us that the behavior of 
microorganisms against antibiotics has had a side effect on the expression of resistance to heavy metals as a consequence of the presence of genes in the same plasmid, which can confer resistance to these compounds [31]. Simultaneously, the presence of heavy metals in an ecosystem can lead to the development of microorganisms resistant to these contaminants, as well as antibiotics. Antibiotic and metal resistant microorganisms appear to be the result of exposure to metal contaminated environments causing a coincident selection of resistance factors for both [24].

\section{Conclusion}

The presence of $E$. coli pathogen in the effluent of the Atoyac river was identified, and showed resistance to 12 antibiotics, with resistance to the antibiotics Carbenicillin (CB), Ampicillin (AM) and Sulfamethoxazole/Trimethoprim (SXT) prevailing. Strains isolated showed multiple resistance between 4 to 10 antibiotics with 23 patterns of antimicrobial resistance. All strains isolated showed resistance to heavy metals: Molybdate (NaMoO4) and Iron (FeCl3) and to Lead $(\mathrm{Pb})$ only 5.3\%, the results revealed the existence of EPEC capable of resisting more than 1 type of antibiotic and heavy metals.

\section{Compliance with ethical standards}

\section{Acknowledgments}

All authors listed have made a substantial and intellectual contribution to the work, and approved it for publication.

\section{Disclosure of conflict of interest}

The authors declare no conflict of interest.

\section{References}

[1] Martínez AM, Veranes O, Carballo ME, Salgado I, Olivares S, Lima L and Rodríguez D. (2017). Resistencia a antibióticos y a metales pesados en bacterias aisladas del río Almendares. Revista CENIC Ciencias Biológicas, 41, $1-10$.

[2] Olguín EJ, González RE, Sánchez G, Zamora JE and Owen T. (2010). Contaminación de ríos urbanos: El caso de la subcuenca del río Sordo en Xalapa, Veracruz, México. Revista Latinoamericana de Biotecnologia Ambiental y Algal, 1, 178-190.

[3] Arcos M, Avila S, Estupiñán SM and Gómez AC. (2005). Indicadores microbiológicos de contaminación de las fuentes de agua. Revista NOVA Publicación Científica en Ciencias Biomédicas, 3, 69-79.

[4] Tzoc E, Arias ML and Valiente C. (2004). Efecto de las aguas residuales hospitalarias sobre los patrones de resistencia a antibióticos de Escherichia coli y Aeromonas sp. Revista Bimomédica, 15, 165-172.

[5] Dreser A, Wirtz VJ, Corbett KK and Echániz G. (2008). Uso de antibióticos en México: revisión de problemas y políticas. Salud Pública de México, 50, 480-487.

[6] Cervantes C, Espino AE, Acevedo F, León IL, Rivera ME, Avila M, Wróbel K, Wróbel K, Gutiérrez JF, Rodríguez JS and Moreno R. (2006) Interacciones microbianas con metales pesados. Revista Latinoamericana de Microbiologia, 48, 203-210.

[7] Ruvalcaba JC, Rosas I, Pertuz SB, Interían L and Raygoza AM. (2014). Bacteriological indicators on the environment and in human healt. Current World Environment, 9, 96-104.

[8] Somda NS, Bonkoungou OJI, Zongo C, Kpoda DS, Tapsoba F, Bassolé IHN, Traoré Y and Savadogo A. (2017). Prevalence of Escherichia coli virulence genes in patients with diarrhoea in ouagadougou, burkina faso. African Journal of Clinical and Experimental Microbiology, 18, 179-185.

[9] Huang WC, Hsu BM, Kao PM, Tao CW, Ho YN, Kuo CW and Huang YL. (2016). Seasonal distribution and prevalence of diarrheagenic Escherichia coli in different aquatic environments in Taiwan. Ecotoxicology and Environmental Safety, 124, 37-41.

[10] Ramírez FY, Avelar FJ, Garneau P, Márquez F, Guerrero AL and Harel J. (2013). Presence of multi-drug resistant pathogenic Escherichia coli in the San Pedro River located in the State of Aguascalientes, México. Frontiers Microbiology, 4, 1-16. 
[11] Obi CL, Green E, Bessong PO, De Villiers B, Hoosen AA, Igumbor EO and Potgieter N. (2004). Gene encoding virulence markers among Escherichia coli isolates from diarrhoeic stool samples and river sources in rural Venda communities of South Africa. Water SA, 30, 37-42.

[12] Ahmed W, Neller R and Katouli M. (2005). Host species-specific metabolic fingerprint database for enterococci and Escherichia coli and its application to identify sources of fecal contamination in surface waters. Applied Environmental Microbiology, 71, 4461-4468.

[13] Mendes D and Domingues L. (2015). On the track for an efficient detection of Escherichia coli in water: A review on PCR-based methods. Ecotoxicology and Environmental Safety, 113, 400-411.

[14] Méndez RI, San Pedro L, Castillo ER and Vázquez E. (2010). Modelación del tiempo de conservación de muestras biológicas de agua. Revista Internacional de Contaminación Ambiental, 26, 327-335.

[15] Vila J, Alvarez M, Buesa J and Castillo J. (2009). Diagnóstico microbiológico de las infecciones gastrointestinales. Enfermedades Infecciosas y Microbiologia Clinica, 27, 406-411.

[16] Megchún JV, Landeros C, Soto A, Castañeda MR, Martínez JP, Nikolskii I, Galaviz I and Lango F. (2015). Total coliforms and Escherichia coli in surface and subsurface water from a sugarcane agroecosystem in Veracruz, México. Journal of Agricultural Science, 7, 110-119.

[17] Rivera JA, Cedillo L, Guzmán M and Giono S. (2006). Diagnóstico de enterobacterias en el río Alseseca. Revista de la Facultad de Medicina de la UNAM, 49, 20-22.

[18] Nontongana N, Sibanda T, Ngwenya E and Okoh AI. (2016). Prevalence and antibiogram profiling of Escherichia coli pathotypes isolated from the Kat river and the fort beaufort abstraction water. International Journal Environmental Research Public Health, 11, 8213-8227.

[19] Chávez E, Rivera JA, Castañeda, EI, Gil JC, Ochoa MA and Cedillo ML. (2012). Multiresistencia antimicrobiana de Escherichia coli enteropatógena y enterotoxigénica, detectadas en muestras clínicas mediante reacción en cadena de la polimerasa. Revista Ciencias Biomédicas, 3, 40-48.

[20] Stange C, Sidhu JPS, Tiehm A and Toze S. (2016). Antibiotic resistance and virulence genes in coliform water isolates. International Journal of Hygiene and Environmental Health, 219, 823-831.

[21] Romeu B, Salazar P, Lugo D, Rojas NM and Eslava CA. (2012). Susceptibilidad antimicrobiana de aislamientos de Escherichia coli procedentes de ecosistemas dulceacuícolas. Revista Cubana de Medicina Tropical, 64, $132-141$.

[22] Chindembele JM, Romeu B, Chivela M, Resto GA and Rojas NM. (2015). Evaluación de la resistencia antimicrobiana de cepas de Escherichia coli causantes de infecciones urinarias en la provincia de Huambo, Angola. Revista Cubana de Ciencias Biológicas, 4, 71-77.

[23] Delgado ME, Tamez P, Gómez R, Zavala FJ, Eroza G, Nevárez GV, Pérez MC, Sánchez B, González M and Infante R. (2016). Multidrug-resistant bacteria isolated from surface water in Bassaseachic Falls National Park, Mexico. International Journal of Environmental Research Public Health, 13, 3-15.

[24] Abskharon RNN, Hassan SHA, Gad El-Rab SMF and Shoreit AAM. (2008). Heavy metal resistant of E. coli isolated from wastewater sites in Assiut City, Egypt. Bulletin of Environmental Contamination and Toxicology, 81, 309315.

[25] Chávez E, García M, Avelino F, Gil C and Castañeda EI. (2007). Identificación de tres factores de virulencia en cepas de Escherichia Coli aisladas de humanos. Enfermedades Infecciosas y Microbiologia, 27, 114-117.

[26] Marrero J, Díaz A and Coto 0. (2010). Mecanismos moleculares de resistencia a metales pesados en las bacterias y sus aplicaciones en la biorremediación. Revista CENIC Ciencias Biológicas, 41, 67-78.

[27] Sandoval AM, Pulido G, Monks S, Gordillo AJ and Villegas EC. (2009). Evaluación fisicoquímica, microbiológica y toxicológica de la degradación ambiental del río Atoyac, México. Interciencia, 34, 880-887.

[28] Lamprecht C, Romains M, Huisamen N, Carinus A, Schoeman N, Sigge GO and Britz TJ. (2014). Escherichia coli with virulence factors and multidrug resistance in the Plankenburg River. South African Journal of Science, 110, 1-6.

[29] Adefisoye MA and Okoh AI. (2016). Identification and antimicrobial resistance prevalence of pathogenic Escherichia coli strains from treated wastewater effluents in Eastern Cape, South Africa. Microbiology Open, 5, 143-151. 
[30] Novoa O, Frati AC, Peredo MA, Flores S, Novoa O, Galicia J and Romero CE. (2017). Susceptibility to rifaximin and other antimicrobials of bacteria isolated in patients with acute gastrointestinal infections in Southeast Mexico. Revista de Gastroenterología de México, 82, 226-233.

[31] Veranes 0. (2013). Evaluación de la resistencia a antibióticos y a metales pesados en aislados bacterianos del río Almendares. Revista CENIC Ciencias Biológicas, 44, 35-37.

\section{How to cite this article}

Chávez-Bravo E, Cordero-Arellano CC, Alonso-Calderón AIA and Rivera A. (2020). Enteropathogenic Escherichia coli in a treated effluent from Puebla City-Mexico, resistant to antibiotics and heavy metals. GSC Advanced Research and Reviews, 3(3), 69-78. 